\title{
A Rare Cause of Colon Perforation; Intrauterin Device
}

\author{
Nadir Görülen Bir Kolon Perforasyon Nedeni; Rahim İçi Araç
}

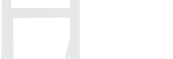

${ }^{1}$ Ergani State Hospital, Clinic of General Surgery, Diyarbakır, Turkey

3 Selahaddin Eyyubi State Hospital, Clinic of General Surgery, Diyarbakır, Turkey

${ }^{4}$ Nizip State Hospital, Clinic of General Surgery, Gaziantep, Turkey

ABSTRACT

Intrauterin device (IUD) is one of the most common used contraseptive methods in the world. Migration of IUD to sigmoid colon is a rare and serious complication. This report represents a case with an acute abdominal condition due to a migrating IUD which perforated the uterus and migrated to and perforated the sigmoid colon. IUD was removed from the abdomen laparoscopically and at the same session, laparoscopic repair of the sigmoid colon and uterus were performed. Laparoscopy is a reliable method for patients with lost intra-abdominal IUD which migrates by perforating the uterus. It enables repair of organ perforations at the same session and provides less tissue damage by minimal incision, less postoperative pain and decreased risk of intra-abdominal adhesion and therefore, facilitating the patient's comfort and decreasing duration of hospitalization.
\end{abstract}

Keywords: Sigmoid colon perforation, uterus perforation, intrauterin device, laparoscopy

(D) Onur Olgaç Karagülle¹, (D) Erkan Yavuz², (D) Hüseyin Bilge3 ${ }^{3}$ (D) Barış Sana4, (D) Aydın Zilan², (D) Fatih Çelebi²

2istanbul Bağcılar Training and Research Hospital, Clinic of General Surgery, i̇stanbul, Turkey

\section{öZ}

Rahim içi araç (RIA) dünyada en sık kullanılan kontraseptif yöntemlerinden biridir. RİA'nın sigmoid kolona migrasyonu nadir görülen ciddi bir komplikasyondur. Bu çalışmamızda uterusu perfore ederek sigmoid kolona migrasyon yapan ve kolon perforasyonu olușturarak akut batın kliniği veren hastamızda, RíA'nın laparoskopik olarak batın dışına çıkarılmasını ve aynı seansta laparoskopik sigmoid kolon ve uterus onarımının yapılmasını sunduk. Uterus perforasyonu oluşturarak migrasyon yapmış kayıp batın içi RíA olgularında laparoskopi güvenilir bir yöntem olup, aynı seansta organ perforasyonlarının tamirine de olanak sağlamakta ve minimal insizyonla daha az doku travması, daha az postoperatif ağrı ve azalmış intra-abdominal adezyon riski sağlayarak hasta konforu ve yatış süresinin kısalmasına olanak tanımaktadır.

Anahtar Kelimeler: Sigmoid kolon perforasyonu, uterus perforasyonu, rahim içi araç, laparoskopi

\section{Introduction}

Intrauterine device (IUD) is one of the most common and reversible contraception methods (1). Although the long-term and systematic side effects of IUD are minimal, it can cause mortality due to migration of the device to neighboring organs. The rate of uterine perforation due to IUD is reported as $0.05-13 / 1000$ in the literature (2). As a result of the migration of IUD; ischemia, perforation, obstruction and mesenteric injury may occur in the small and large intestines. Complications such as migration to luminal organs, adhesions and infection in peritonial cavity have also been reported (3). After perforation, IUD migrates to adjacent organs such as appendix, peritoneum, omentum and bladder, and sigmoid colon perforation was rarely presented as a case report (4). Laparoscopy can be used in cases in whom IUD is lost in abdomen by migrating outside the uterus for both diagnostic purpose and for therapeutical purpose to repair organ damage. In this study, we showed the removal of IUD, which migrated to sigmoid colon and caused perforation, outside abdomen and repairing of sigmoid colon and uterus by laparoscopy.

\section{Case Report}

A 31-year-old female was admitted to emergency service with left-lower quadrant pain. The patient had a history of IUD placement 1 year ago. She had left-lower quadrant pain for 10 days and it worsened for 1 day. The nullipara patient had no other feature in medical history, her hemodynamics were stable and body her temperature was normal. In examination, she had tenderness in the left-lower quadrant of abdomen and systemic examinations were normal. Leucocyte count was 11.13/ $\mathrm{mm}^{3}$ in hemogram and other parameters were normal. 
In gynaecological examination, it was thought that IUD had left the myometrium of uterus and went out of the serosa, when the tail of IUD was not observed and the transvaginal ultrasonography did not show the echogenicity of IUD. Laparoscopic exploration was planned for the patient with acute abdomen findings. Laparoscopic surgery was performed under general anesthesia. In exploration, the sigmoid colon was attached to the posterior wall of the uterus. Uterus was perforated by the IUD and half of the IUD was in the sigmoid colon (perforation). Laparoscopic surgery was continued with 3 trocars and the colon adhesions on the back wall of the uterus were opened. In the sigmoid column, IUD was removed from the $0.5 \mathrm{~cm}$ perforation area and taken out of the abdomen (Figure 1). This defect was repaired with $2 / 0$ silk suture (Dogsan, İstanbul, Turkey). Colporrhapy was performed (Figure 2) and the defect in the posterior wall of the uterus was repaired primarily. The abdomen was washed with saline and then was aspirated. Following hemostasis control, the operation was laparoscopically completed by placing 1 drain into the neighbourhood of colon repair area. She was

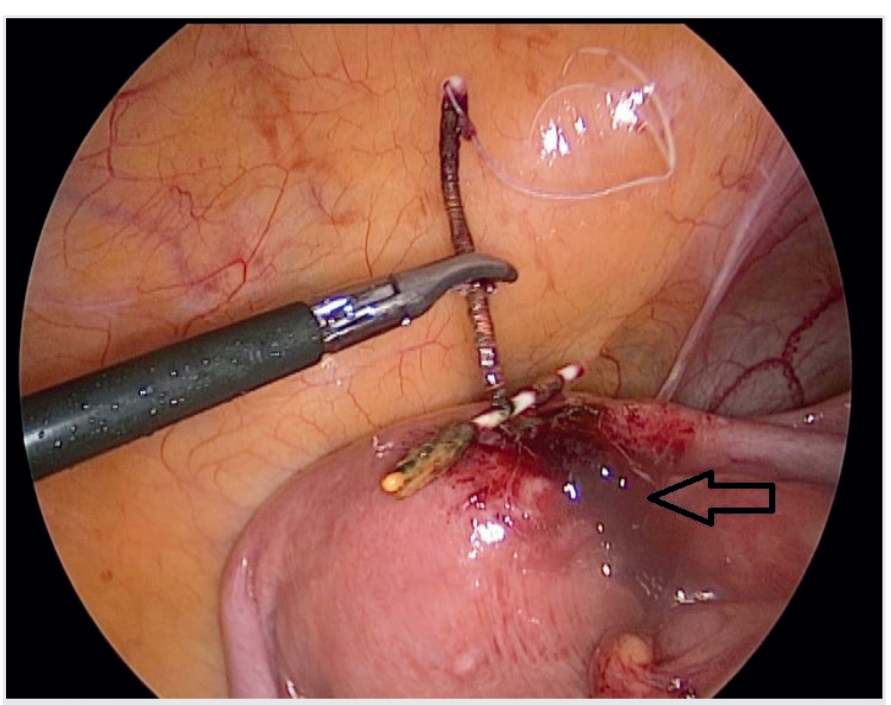

Figure 1. Removal of intrauterine device from uterus and sigmoid colon, laparoscopically; the site of perforation in uterus (Black arrow)

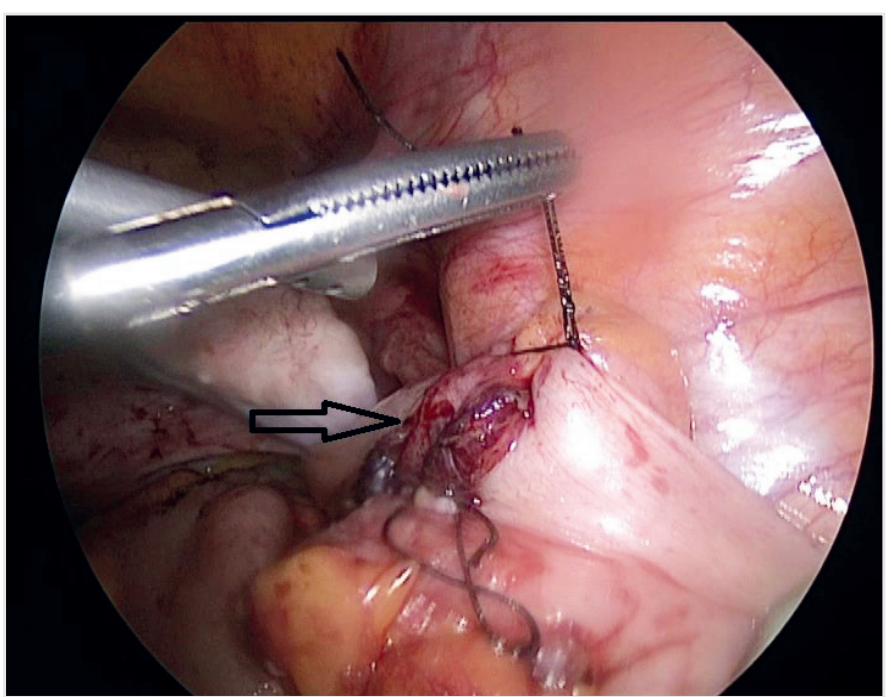

Figure 2. Laparoscopic repair of sigmoid colon which was perforated by intrauterine device discharged without complications in the postoperative $5^{\text {th }}$ day. The patient was followed up in the outpatient clinic after discharge. There were no complications requiring surgical or medical treatment in the control of the patient. Informed consent was obtained from the patient to use her data in this study.

\section{Discussion}

The using rate of IUD as a contraceptive method in developed countries is $9.4 \%$ and $16.4 \%$ in undeveloped countries (5). In recent years, use of IUD has decreased with the belief that it increases the risk of infection (6). In addition to the experience of the health personnel performing IUD, anatomic position of uterus is a risk factor for perforation and organ injury. Although perforations are usually from the posterior or fundal wall of uterus, these perforations are often thought to occur during the insertion process $(7,8)$. The time between migration of IUD to abdomen and adjacent organ injury was reported as 17 months on average (9). In our case, this time was 12 months. Perforation may not be noticed immediately after the placement of IUD. Abdominal pain and uterine bleeding may be seen and also some patients may be asymptomatic. Among intestinal segments, IUD migrates mostly to the rectum, sigmoid colon and small intestines (10). In our case, IUD migrated to sigmoid colon and the patient was clinically asymptomatic for 1 year after IUD placement.

In order to determine the localization of IUD which is lost, ultrasonography, direct graphy, hysteroscopy, computed tomography and surgery may be performed (11). The perforation of the sigmoid colon can be detected insidentally and also it can present with pain and lower gastrointestinal system bleeding (12).

Andersson et al. (13) reported that patients admitted in the late period were mostly asymptomatic and the most common finding in patients admitting in the early period (first one month) was left-lower quadrant pain.

In our case with left-lower quadrant tenderness, diagnostic laparoscopy was performed due to suspected dislocation of the uterus based on the findings that the tail of IUD was not seen in vaginal examination and IUD was not detected in the uterine cavity in ultrasonography.

In diagnostic laparoscopy, uterus and sigmoid colon were attached to each other and formed an inflamed appearence and laparoscopic exploration was continued. In our case, half of the IUD was observed in sigmoid colon and the other half in uterus myometrium. IUD was taken out of uterus and sigmoid colon. The perforation of the sigmoid colon and uterus was repaired laparoscopically and the operation was completed. In the literature, although IUD's migration to sigmoid colon was rarely reported, laparoscopy was used in the diagnosis of similar organ migration cases, but laparotomy was often chosen for organ repair.

Laparoscopic surgery procedures are procedures that require experience and training. Laparoscopy was associated with less postoperative pain, increased quality of life after discharge, early return to normal physical activity, decreased intraabdominal adhesion risk, early discharge and decreased risk of incisional hernia in the long-term period compared with conventional surgery (14). 
Intrauterin device migrated to abdominal cavity can cause recurrent pain, intestinal obstruction, and infertility by forming adhesions. Therefore, IUD should be removed if not seen in the uterine cavity, even if the patient does not have symptoms (15).

\section{Conclusion}

The fact that we used laparoscopy for both diagnosis and repair of sigmoid colon and uterus makes our case different from similar cases in the literature. The use of laparoscopy in cases with IUD located outside the uterin cavity for both diagnosis and repairing the organs contributes to the improvement in postoperative quality of life of the patients.

Informed Consent: Informed consent was obtained from the patient to use her data in this study.

Peer-review: Externally and internally peer-reviewed.

Author Contributions: Concept - 0.O.K., F.Ç.; Design - 0.O.K., F.C..; Supervision - 0.O.K., E.Y.; Resources - H.B., B.S., A.Z., 0.O.K.; Materials - B.S., A.Z.; Data Collection and/or Processing - E.Y., H.B.; Analysis and/ or Interpretation - 0.O.K., A.Z.; Literature Search - H.B., B.S.; Writing Manuscript - O.O.K., E.Y.; Critical Review - E.Y., F.C.., B.S.

Conflict of Interest: No conflict of interest was declared by the authors.

Financial Disclosure: The authors declared that this study received no financial support.

\section{References}

1. Ertopçu K. Intrauterin device. Turkiye Klinikleri J Gynecol Obst-Special Topics 2012; 5: 37-42.

2. Grimaldi L, DeGeorgio F, Andreotta P, D Alessio MC, Piscicelli C, Pascali VL. Mediolegal aspect of an unusual uterine perforation with multiload-Cu 375 R. Am J Forensic Med Pathol 2005; 26: 365-6.
3. Arslan A, Kanat-Pektas M, Yesilyurt H, Bilge U. Colon penetration by a copper intrauterine device: a case report with literature review. Arch Gynecol Obstet 2009; 279: 395-7.

4. Öztürk Z, Usta T, Acet M, Ateș U, Sidal B. Sigmoid kolonda Rahim içi aracın incidental tespiti. Göztepe Tıp Dergisi 2010; 25: 91-2.

5. Akpınar F, Özgür EN, Yılmaz S, Ustaoğlu O. Sigmoid colon migration of an intrauterine device. Case Rep Obstet Gynecol 2014; 2014: 207659.

6. Hubacher D, Chen PL, Park S. Side effects from the copper intrauterine device: do they decrease over time? Contraception 2009; 79: 356-62.

7. Medina TM, Hill DA, Delesus S, Hoover F. IUD removal with colonoscopy: a case report. J Reprod Med 2005; 50: 547-9.

8. Heartwell SP, Schlesselman S. Risk of uterine perforation among users of intrauterine devices. Obstet Gynecol 1983; 61: 31-6.

9. Chen CP, Hsu TC, Wang W. Ileal penetration by a MultiloadCu 375 intrauterine contraceptive device. A case report with review of the literature. Contraception 1998; 58: 295-304

10. Bilge Z, Öztaș E, Özderin Özin Y, Öztaș E, Dișibeyaz S. An foreign body inside rectum; intrauterine device. Endoscopy Gastrointestinal 2015; 23: 62-3.

11. Sentilhes L, Lefebvre-Lacoeuille C, Poilblanc M. Incidental finding of an intrauterine device in the sigmoid colon. Eur J Contracept Reprod Health Care 2008; 13: 212-4.

12. Tinelli A, Tinelli R, Malvasi A, Cavallotti C, Tinelli FG. The intrauterine device in modern contraception: Still an actuality? Eur J Contracept Reprod Health Care 2006; 11: 197-201.

13. Andersson K, Ryde-Blomqvist E, Lindell K, Odlind V, Milsom I. Perforation with intrauterine devices. Report from a Swedish survey. Contraception 1998; 57: 251-5.

14. Altınel Ö, Demirbaş S. Laparoskopik Kolorektal Cerrahi review. Türkiye Klinikleri J Gen Surg-Special Topics 2011; 4: 51-9.

15. Alanbay I, Çoksüer H, Güler AE, Ercan M, Keskin U, Karaşahin E, et al. Intraabdominal kayıp rahim içi aracın laparoskopik olarak çıkarılması; Olgu sunumu ve literatür incelemesi. Cumhuriyet Tıp Derg 2011; 33: 365-s9. 